\title{
The Relation between the Lifelong Learning Competencies and Occupational Motivation Levels of the Teachers Who Received Postgraduate Education
}

\author{
Bülent Özden \\ Departmentof Elementary Education, Marmara University, Istanbul, Turkey \\ E-mail: bulent.ozden@marmara.edu.tr
}

Aslıhan Alyıldız Uğurlu (Corresponding author)

Departmentof Elementary Education, Recep Tayyip Erdoğan University, Rize, Turkey

E-mail: aslihan.alyildizugurlu@erdogan.edu.tr

\begin{abstract}
Elif Sarıcan
Department of Educational Sciences, Marmara University, Istanbul, Turkey

E-mail: esarican@marmara.edu.tr
\end{abstract}

Received: March 5, 2019 Accepted: April 14, 2019 Published: April 24, 2019

doi:10.5296/jei.v5i1.14457 URL: https://doi.org/10.5296/jei.v5i1.14457

\begin{abstract}
The aim of this study is to determine the relationship between lifelong learning competencies and occupational motivation level of the teachers who completed postgraduate education. The research was designed in accordance with the correlational research model. A total of 52 teachers (41 female and 11 male) attending Marmara University's Institute of Educational Sciences in different disciplines were selected using the simple random sampling method. Their average of age is 25 . The data of the study were collected through Lifelong Learning Key Competencies Scale and Occupational Motivation Scale. Results showed that the lifelong learning competencies of the teachers who received postgraduate education are sufficient or very sufficient. Results also showed that the level of occupational motivation of the teachers with postgraduate education is high.
\end{abstract}

Keywords: Occupational motivation, Lifelong learning, Graduate studies 


\section{Mll Macrothink}

\section{Introduction}

The concept of lifelong learning has had international currency since at least 1972, with the appearance of the Final Report of Unesco's International Commission on the Development of Education (Candy, 2003). At the beginning of the twenty-first century, many international organizations and national states articulated the concept of lifelong learning (Coolahan, 2002). In the last decade, significant transformations took place in the field of adult education and lifelong learning in many countries (Biesta, 2006).

Although the concept of lifelong learning is used in various contexts and has multiple interpretations, its meaning is mostly vague (Aspin \& Chapman, 2000). Although lifelong learning has no universally accepted definition, it can be widely defined as the education of a workforce that can keep up with the changing world in the information age (Sharples, 2000). For education to be lifelong, life-wide, and learner centered learning, teachers need to be active lifelong learner (Woonsun, 2014). Lifelong learning is transforming the education and training of the individuals from something limited to just one part of their lives into a process that will last for their whole lives and something that can take place anywhere; at home, at work, or at a café. Lifelong learning also means offering a second chance to individuals by updating their basic skills and a gateway for more advanced education possibilities (Soran, Akkoyunlu, \& Kavak, 2006).

Globalization and the advancements in science and technology became the main factors that set the necessary workforce profiles for our contemporary societies. In other words, societies today require individuals that "develop themselves" and have "lifelong learning" skills (Soran, Akkoyunlu, \& Kavak, 2006). The lifelong learning skills, which are among the qualities of modern humans, can be summarized as the following (Budak, 2009):

Ability to set personal learning goals;

$\checkmark$ Ability to utilize information; finding information, accessing resources, interpretation, management and utilization of different resources;

$\checkmark \quad$ Intellectual curiosity, critical thinking and a love of learning;

$\checkmark$ Planning and controlling of personal learning process;

$\checkmark$ Reasoning and self-assessment;

$\checkmark$ Making evaluations based on development and transformation;

$\checkmark$ Effective participation in formal or informal teaching;

$\checkmark$ Accessing information from different resources and evaluating different information;

$\checkmark \quad$ Learning interactively and synthesizing ideas from different fields;

$\checkmark$ Adopting different learning strategies according to the needs;

$\checkmark \quad$ Learning by focusing on real life problems;

$\checkmark \quad$ Learning by focusing on process and content; 


\section{Macrothink}

$\checkmark$ Having a wide perspective and awareness of relations in different fields;

$\checkmark$ Absorbing information sufficiently enough to transfer it to other fields;

$\checkmark$ A love of learning and the ability to organize information according to positive self-conception;

$\checkmark$ Ability to evaluate one's self according to internal or external measurements.

The characteristics of lifelong learning individuals can be described as the following: curious and enthusiastic, able to identify and plan personal educational needs, able to reach information, able to evaluate the value of the acquired information, able to question and critically review the acquired information. In order for the information acquired through lifelong learning to be useful, individuals need to have qualities, such as the ability to implement the information, the ability to transfer the information into new situations and the ability to reassess their past experiences to correct previous mistakes. For a lifelong learner, learning how to learn and knowing where to look and which resources to use are important skills (Yıldırım, 2017).

Not limiting education in a period of time and prolonging it for the whole duration of life are important in terms of adapting to life and continuing to be a certain qualities (Erdamar, 2015). Although the concept of lifelong learning becomes prominent in contemporary societies, it is, in fact, a requirement for the human survival since the beginning of humanity (Yildirim, 2017). Therefore, an educational structure emphasizing lifelong learning skills must be embraced and individuals with such skills must be trained in accordance with certain principles in order to meet this need.

The principles of lifelong learning set by the State Planning Agency (2001) are as follows:

$\checkmark$ Termination of encyclopedic information;

$\checkmark$ Termination of illiteracy;

$\checkmark$ Termination of the transfer of information by old means;

$\checkmark$ Termination of excessive specialization;

$\checkmark$ Termination of traditional teaching methods at all levels;

$\checkmark$ Democratization of education (DPT, 2001).

A society composed of lifelong learners can constructed with arrangements to the educational system (Evin-Gencel, 2013). Helping students understand themselves better is not enough to transform them into lifelong learners; we must realize that their lives are much more complex than that. They do not leave their own lives outside when they enter the classroom. What we need to do is open the doors of communication and become learners ourselves in order to grow and develop with them (Ward, 2006).

The basis of the lifelong learning is the concept of accepting change as a fact. It includes creating a labor market that can withstand change and building a future-oriented human 
resources environment which can provide the new jobs and skills that will emerge due to change (DPT, 2001; Tunca, Alkın-Şahin, \& Aydın, 2015). Nowadays it became nearly impossible for a person to do their job all for their whole life in an effective way with only the knowledge and skills they acquired in school. Individuals need to participate in different trainings, acquire new knowledge and regenerate themselves (Ayra, Kösterelioğlu, \& Çelen, 2016).

Lifelong learning is a process related to three levels, which are ideally associable with the periods of life and individual development. In short, there are three development levels: Individual and cultural development (i.e., the meaning given to one's life); social development (i.e., one's citizenship, political participation and co-existence in the society); and finally, occupational development (i.e., production, job satisfaction, and high quality and stable employment with material prosperity) (UNESCO, 2005).

Occupational development is a sub-process that falls under lifelong learning. The concept of occupational development evolved alongside the concepts of in-service training, staff development, career development, and human resources development (Bümen, Ateş, Çakar, Ural, \& Acar, 2012). Occupational motivation appears to be an important factor in the conceptualization of all of these terms.

The occupational motivation can be defined as "Internally or externally emerging forces that initiate one's occupational behavior and determine their form, direction, intensity and continuity". Occupational motivation is the psychological process that consists of the behaviors and endeavors of workers to complete a duty or to achieve a material or immaterial benefit (Zeynel, 2014). Occupational motivation is a set of energetic forces that originate both within as well as beyond an individual's being, to initiate work-related behavior and to determine its form, direction, intensity, and duration (Pinder, 1998; Latham \& Pinder, 2005).

Lifelong learning plays an important role in healthy continuity of occupational development. Similar to lifelong learning skills, occupational motivation is important for an individual to continue to develop themselves in their occupation. That is why the goal of this study was to investigate the relation between the occupational motivation levels and the lifelong learning skills of the teachers who received postgraduate education. In this direction, the following questions were asked:

(1) What are the competency levels of the teachers who received postgraduate education?

(2) How high is the occupational motivation of the teachers who received postgraduate education?

Moreover, the following hypotheses were also tested:

(1) Hypothesis: The occupational motivation of the teachers who received postgraduate education is not a predictor for their lifelong learning competencies

(2) Hypothesis: The occupational motivation of the teachers who received postgraduate education is not a predictor for the sub-dimensions of their lifelong learning competencies 
(3) Hypothesis: The occupational motivation of the teachers who received postgraduate education is not a predictor for their lifelong learning skills and the sub-dimensions of their lifelong learning competencies.

\section{Method}

This study aims to determine whether occupational motivation is a significant predictor of their lifelong learning competencies for the teachers who received postgraduate education. For this purpose, the study was designed according to the correlational research method. The correlational research is a type of research in which the relation between two variables is investigated without interfering with them (Büyüköztürk, Kılıç, Akgün, Karadeniz, \& Demirel, 2012).

The sample consisted of 52 teachers, 41 of whom were women and 11 were men. They were all students of the Marmara University in different departments in Turkey. The sample consists of 10 social science teachers, 9 music teachers, 8 elementary teachers, 7 mathematics teachers, 7 science teachers and 9 preschool teachers. All teachers have master's degree in their field. Their average of age is 25 . The sample was selected using the simple random sampling method. However, the data obtained from 12 teachers were disregarded to ensure normal distribution, and thus, the sample size was reduced to 40 .

The lifelong learning key competencies scale and occupational motivation scale were used to determine the occupational motivation and lifelong learning competency levels of the teachers who received postgraduate education.

\subsection{Lifelong Learning Key Competencies Scale}

The study uses the Lifelong Learning Key Competencies Scale developed by Şahin, Akbaşl1 and Yanpar-Yelken (2010) by analyzing the European Commission Reports of 2005. The five-point Likert scale consists of eight different subsections: Communication in native language; communication in foreign language; mathematics, science and technology competencies; digital competence; learning to learn; social, intercultural and citizenship competencies; entrepreneurship; cultural consciousness and expression. There are 23 articles in the scale. The lowest possible score in the scale is 23 and the highest is 115. Cronbach Alpha Safety Coefficient of the scale was found 0.75. In this study this value was found 0.72 . The values of the Cronbach Alpha for the sub-dimensions of the scale were as follows: Native language communication competency .778, foreign language communication competency .940 , basic mathematical competency in science and technology .670, digital competency .797 , learning to learn competency .840 , social citizenship competency .846 and initiative and entrepreneurship comprehension competency .849 . Because of the cultural consciousness and expression competency consist of one item, the value of the Cronbach Alpha could not calculated for this sub-dimension.

\subsection{Occupational Motivation Scale}

The Occupational Motivation Scale was developed by Ural (1996) and later revised by Ural and Efe (2007). There are 24 articles in the scale. The scale has five subsections: Job 
satisfaction, sense of duty, economic insufficiency of job, occupational limitations, and economic benefits of the job. The minimum scores in this four-point Likert scale are the following; job satisfaction 28, sense of duty 16, economic insufficiency of the job 16, occupational limitations 16 and economic benefits of the job 12. Cronbach Alpha Safety Coefficient of the scale was found .91 by Ural and Efe (2007). In this study this value was found .854. The values of the Cronbach Alpha for the sub-dimensions of the scale were as follows: Job satisfaction .775, sense of duty .824, economic insufficiency of job .746, occupational limitations .698 and economic benefits of job .712. Kolmogorov-Smirnov normality analysis was conducted on the collected data before the actual analysis. Kolmogorov-Smirnov analysis showed that the data collected with both the Occupational Motivation Scale $(Z=.116 ; p=.116 ; p>.05)$ and Lifelong Learning Scale $(Z=.066 ; p$ $=.200 ; \mathrm{p}>.05)$ are normally distributed.

Descriptive statistical analyses were made to determine the occupational motivation and lifelong learning competency levels of the teachers who received postgraduate education. Moreover, simple linear and multiple regression analyses were used to test the hypotheses of the study.

The scores of the teachers in the lifelong learning key competencies scale were interpreted using the following table:

Table 1. The evaluation of the scores in the lifelong learning key competencies scale

\begin{tabular}{|c|c|c|c|c|c|}
\hline & Very insufficient & Insufficient & Neutral & Sufficient & Very sufficient \\
\hline $\begin{array}{l}\text { Native language } \\
\text { communication competency }\end{array}$ & \multirow{3}{*}{$1-4$} & \multirow{3}{*}{$5-8$} & \multirow{3}{*}{$9-12$} & \multirow{3}{*}{$13-16$} & \multirow{3}{*}{$17-20$} \\
\hline $\begin{array}{l}\text { Foreign language } \\
\text { communication competency }\end{array}$ & & & & & \\
\hline $\begin{array}{l}\text { Initiative and entrepreneurship } \\
\text { comprehension competency }\end{array}$ & & & & & \\
\hline $\begin{array}{l}\text { Basic mathematical competency } \\
\text { in science and technology }\end{array}$ & \multirow[t]{2}{*}{$1-3$} & \multirow[t]{2}{*}{$4-6$} & \multirow[t]{2}{*}{$7-9$} & \multirow[t]{2}{*}{$10-12$} & \multirow[t]{2}{*}{$13-15$} \\
\hline Social citizenship competency & & & & & \\
\hline Digital competency & \multirow{2}{*}{$1-2.6$} & \multirow{2}{*}{$2.7-4.3$} & \multirow{2}{*}{$4.4-6$} & \multirow{2}{*}{$6.1-7.7$} & \multirow{2}{*}{$7.8-10$} \\
\hline Learning to learn competency & & & & & \\
\hline $\begin{array}{l}\text { Cultural consciousness and } \\
\text { expression competency }\end{array}$ & $1-1.8$ & $1.9-2.7$ & $2.8-3.6$ & $3.7-4.5$ & $4.6-5$ \\
\hline Lifelong learning competency & $23-41$ & $42-60$ & $61-79$ & $80-98$ & $99-115$ \\
\hline
\end{tabular}




\section{MIN Macrothink}

\section{Findings}

The analysis results of the descriptive statistics to determine the occupational motivation levels of the teachers who received postgraduate education are shown in Table 2 below.

The analysis of the occupational motivation scale regarding the teachers who received postgraduate education showed that their mean score was 74.80 . The highest score possible in the scale is 88 . Therefore, under the light of their mean score, it can be concluded that the teacher's occupational motivation is very high.

Table 2. The descriptive-statistical results of the occupational motivation levels of the teachers who received postgraduate education

\begin{tabular}{|l|l|l|l|l|l|}
\hline & N & Minimum & Maximum & $\bar{X}$ & Ss \\
\hline Occupational motivation & 40 & 63 & 84 & 7.4 .80 & 5.901 \\
\hline Job Satisfaction & 40 & 21 & 32 & 27.08 & 3.174 \\
\hline Sense of duty & 40 & 11 & 16 & 1.4 .48 & 1.552 \\
\hline Economic insufficiency of job & 40 & 8 & 16 & 13.12 & 1.924 \\
\hline Occupational Limitations & 40 & 6 & 13 & 9.98 & 1.790 \\
\hline Economic benefits of job & 40 & 4 & 12 & 8.43 & 1.960 \\
\hline
\end{tabular}

The average score of the teachers with postgraduate education in the sub-dimensions of the occupational motivation scale are as follows: Job Satisfaction 27.08; sense of duty 14.48; the economic insufficiency of the job 13.12; the occupational limitations 91.98, and economic benefits of job 8.43. In terms of teachers' mean scores in the sub-dimensions of the scale, it can be said that they are satisfied with their jobs and they have a high sense of duty. Furthermore, teachers see their jobs as economically insufficient and they perceive the economic benefits and occupational limitations of their job as neutral.

The descriptive-statistical analysis results of sub-dimensions of lifelong learning competency levels of the teachers who received postgraduate education are shown in Table 3. 


\section{Ml Macrothink}

Table 3. The descriptive-statistical results of the sub-dimensions of lifelong learning competency levels of the teachers who received postgraduate education

\begin{tabular}{|l|l|l|l|l|l|l|}
\hline & $\mathrm{N}$ & Minimum & Maximum & $\overline{\mathrm{X}}$ & $\mathrm{S}$ s & Level \\
\hline Lifelong learning competency & 40 & 72 & 107 & 89.57 & 8.681 & Sufficient \\
\hline Native language communication competency & 40 & 13 & 20 & 18.98 & 1.620 & Very Sufficient \\
\hline Foreign language communication competency & 40 & 4 & 16 & 8.39 & 3.370 & Insufficient \\
\hline $\begin{array}{l}\text { Basic mathematical competency } \\
\text { in science and technology }\end{array}$ & 40 & 8 & 15 & 11.87 & 2.267 & Sufficient \\
\hline Digital competency & 40 & 5 & 10 & 8.1 & 1.522 & Very Sufficient \\
\hline Learning to learn competency & 40 & 6 & 10 & 8.86 & 1.132 & Very Sufficient \\
\hline Social citizenship consciousness competency & 40 & 9 & 15 & 12.66 & 2.056 & Very Sufficient \\
\hline $\begin{array}{l}\text { Initiative and entrepreneurship } \\
\text { comprehension competency }\end{array}$ & 40 & 12 & 20 & 16.87 & 2.338 & Very Sufficient \\
\hline $\begin{array}{l}\text { Cultural consciousness } \\
\text { and expression competency }\end{array}$ & 40 & 1 & 5 & 3.87 & 1.069 & Sufficient \\
\hline
\end{tabular}

The mean score of 89.57 indicates that the teachers have a lifelong learning competency at a sufficient level. The teachers perceived themselves to be very sufficient in native language communication competency, digital competency, learning to learn competency, social citizenship consciousness competency and initiative and entrepreneurship sub-dimensions of the scale.

Table 3 reveals that the teachers are sufficient in basic mathematical competency in science and technology and cultural consciousness and expression competency. However, they are only insufficient in foreign language communication competency.

The results of basic linear regression analysis to see whether occupational motivation is a significant predictor of lifelong learning competencies are shown in Table 4.

Table 4. The model summary of basic linear regression analysis of variables of occupational motivation and lifelong learning competencies

\begin{tabular}{|l|l|l|l|l|}
\hline Variables & $\mathrm{R}$ & $\mathrm{R}$ squared & $\mathrm{F}$ & $\mathrm{P}$ \\
\hline Occupational motivation & .080 & .006 & .243 & .625 \\
\hline
\end{tabular}

As seen in Table 4, the results of the analysis of variance about the occupational motivation and lifelong learning competencies of the teachers show that the regression model is not 
statistically significant $(\mathrm{F}=.243 ; \mathrm{p}>.050)$. Therefore, it indicates that occupational motivation is not a significant predictor of the lifelong learning competencies.

The results of the multiple regression analysis to see whether occupational motivation is a significant predictor of the sub-dimensions of lifelong learning competencies are shown in Table 5.

Table 5. The model summary of the multiple regression analysis of the variables for occupational motivation and lifelong learning competencies

\begin{tabular}{|c|c|c|c|c|c|c|}
\hline $\begin{array}{l}\text { Lifelong learning competencies } \\
\text { scale sub-dimensions }\end{array}$ & Variable & $\mathrm{R}$ & $\mathrm{R}$ squared & $\begin{array}{l}\text { Adjusted } \\
\text { R squared }\end{array}$ & $F$ & $P$ \\
\hline $\begin{array}{l}\text { Native language } \\
\text { communication competency }\end{array}$ & \multirow{8}{*}{$\begin{array}{l}\text { Occupational } \\
\text { Motivation }\end{array}$} & .079 & .006 & -.020 & .239 & .628 \\
\hline $\begin{array}{l}\text { Foreign language } \\
\text { communication competency }\end{array}$ & & .220 & .048 & .023 & 1.934 & .172 \\
\hline $\begin{array}{l}\text { Basic mathematical competency } \\
\text { in science and technology }\end{array}$ & & .104 & .011 & -.015 & .418 & .522 \\
\hline Digital competency & & .154 & .024 & -.002 & .926 & .342 \\
\hline Learning to learn competency & & .169 & .028 & .003 & 1.112 & .298 \\
\hline $\begin{array}{l}\text { Social citizenship } \\
\text { consciousness competency }\end{array}$ & & .288 & .083 & .059 & 3.437 & .072 \\
\hline $\begin{array}{l}\text { Initiative and Entrepreneurship } \\
\text { comprehension competency }\end{array}$ & & .113 & .013 & -.013 & .488 & .489 \\
\hline $\begin{array}{l}\text { Cultural consciousness and } \\
\text { expression competency }\end{array}$ & & .213 & .046 & .020 & 1.815 & .186 \\
\hline
\end{tabular}

As shown in Table 5, the results of the variance analysis about occupational motivation and the sub-dimensions of lifelong learning competencies of the teachers show that the regression model is not statistically significant $(\mathrm{p}>.050)$. Therefore, it indicates that occupational motivation is not a significant predictor of the sub-dimensions of lifelong learning competencies.

The results of multiple regression analysis to see whether the sub-dimension of occupational motivation is a significant predictor of the sub-dimensions of lifelong learning competencies are shown in Tables 6, 7, and 8 . 


\section{Ml Macrothink}

Table 6. The model summary of the linear regression analysis of occupational motivation sub-dimensions, lifelong learning competencies and its sub-dimensions

\begin{tabular}{|c|c|c|c|c|c|c|}
\hline $\begin{array}{l}\text { Lifelong learning } \\
\text { competencies dimensions }\end{array}$ & Sub-dimension & $\mathrm{R}$ & R squared & $\begin{array}{l}\text { Adjusted } \\
\text { R squared }\end{array}$ & $\mathrm{F}$ & $P$ \\
\hline Lifelong learning competency & \multirow{9}{*}{$\begin{array}{l}\text { Occupational } \\
\text { Motivation } \\
\text { Sub-dimensions }\end{array}$} & .396 & .157 & .033 & 1.266 & .301 \\
\hline $\begin{array}{l}\text { Native language } \\
\text { communication competency }\end{array}$ & & .275 & .076 & -.060 & .558 & .731 \\
\hline $\begin{array}{l}\text { Foreign language } \\
\text { communication competency }\end{array}$ & & .342 & .117 & -.013 & .899 & .493 \\
\hline $\begin{array}{l}\text { Basic mathematical competency } \\
\text { in science and technology }\end{array}$ & & .430 & .184 & .065 & 1.538 & .204 \\
\hline Digital competency & & .351 & .124 & -.005 & .958 & .457 \\
\hline Learning to learn competency & & .463 & .215 & .099 & 1.859 & .128 \\
\hline $\begin{array}{l}\text { Social citizenship } \\
\text { consciousness competency }\end{array}$ & & .655 & .428 & .344 & 5.089 & .001 \\
\hline $\begin{array}{l}\text { Initiative and Entrepreneurship } \\
\text { comprehension competency }\end{array}$ & & .418 & .175 & .053 & 1.441 & .235 \\
\hline $\begin{array}{l}\text { Cultural consciousness and } \\
\text { expression competency }\end{array}$ & & .548 & .300 & .197 & 2.918 & .027 \\
\hline
\end{tabular}

As shown in Table 6, the variant analysis results of occupational motivation scale sub-dimensions, lifelong learning competencies and its sub-dimensions are only statistically significant for social citizenship consciousness competency and cultural consciousness and expression competency sub-dimensions $(\mathrm{p}<.050)$. Moreover, it can be argued that occupational motivation sub-dimensions are not significant predictors for overall lifelong learning competencies and its other six sub-dimensions $(\mathrm{p}>.050)$.

A close look at Table 6 reveals that the occupational motivation sub-dimensions have a medium level and significant relation with the social citizenship consciousness competency sub-dimension $\left(\mathrm{R}=.655 ; \mathrm{R}^{2}=.428 ; \mathrm{p}<.050\right)$. The sub-dimensions of occupational motivation accounts for 42.8 percent of the total variation in the social citizenship consciousness competency sub-dimension.

The occupational motivation sub-dimensions have a medium level and significant relation with the cultural consciousness and expression competency sub-dimension $\left(\mathrm{R}=.548 ; \mathrm{R}^{2}\right.$ $=.300 ; \mathrm{p}<.050)$. The sub-dimensions of occupational motivation account for 30 percent of the total variation in the cultural consciousness and expression competency sub-dimension.

The results of the multiple regression analysis on the sub-dimensions of occupational 
motivation and social citizenship consciousness competency are shown in Table 7.

Table 7. The results of the multiple regression analysis on the sub-dimensions of occupational motivation and social citizenship consciousness competency

\begin{tabular}{|c|c|c|c|c|c|c|c|c|}
\hline & Variable & $\mathrm{B}$ & $\begin{array}{l}\text { Standard } \\
\text { Deviation }\end{array}$ & $\beta$ & $\mathrm{t}$ & $\mathrm{p}$ & Double $r$ & Limited $r$ \\
\hline \multirow{6}{*}{$\begin{array}{l}\text { Social Citizenship } \\
\text { Consciousness Competency }\end{array}$} & Constant & 3.285 & 3.496 & & .940 & .354 & & \\
\hline & Job Satisfaction & .428 & .122 & .674 & 3.494 & .001 & .397 & .514 \\
\hline & Sense of Duty & .127 & .228 & .098 & .556 & .582 & .161 & .095 \\
\hline & $\begin{array}{l}\text { Economic } \\
\text { Insufficiency of Job }\end{array}$ & -.482 & .200 & -.460 & -2.140 & .022 & -.089 & -.382 \\
\hline & $\begin{array}{l}\text { Occupational } \\
\text { Limitations }\end{array}$ & .338 & .175 & .300 & 1.935 & .061 & .375 & .315 \\
\hline & $\begin{array}{l}\text { Economic Benefits } \\
\text { of Job }\end{array}$ & -.125 & .155 & -.121 & -.806 & .426 & .066 & -.137 \\
\hline
\end{tabular}

As shown in Table 7, the T-test results about the significance of regression coefficients show that the Job Satisfaction and Economic Insufficiency of Job sub-dimensions are significant predictors for the social citizenship competency sub-dimension $(p<.050)$. According to the standardized regression coefficient $(\beta)$, the significance hierarchy of the predictive variables on social citizenship consciousness competency sub-dimension is as follows: Job satisfaction and economic insufficiency of job.

The relation between the job satisfaction and social citizenship consciousness competency sub-dimensions is positive and low-level $(r=.397)$. However, upon checking with the other variables, this relation between these two variables is seen as increasing and becomes positive and medium-level $(\mathrm{r}=.514)$. The relation between economic insufficiency of job and social citizenship consciousness competency sub-dimensions is negative and very weak $(r=-.089)$. However, when the other variables are checked, the relation between these two variables increases and becomes negative and low-level $(r=-.382)$.

According to the results of the regression analysis, the regression equation for the prediction of social citizenship consciousness competency sub-dimension is as follows: Social citizenship consciousness competency $=3.285+.428$ Job satisfaction -.482 Economic insufficiency of job.

The results of the multiple regression analysis on the sub-dimensions of occupational motivation and cultural consciousness and expression competency sub-dimension are shown in Table 8. 


\section{MInstitute Mach $^{m}$}

As shown in Table 8, when the T-test results on the significance of regression coefficients are examined, it appears that only the economic insufficiency of job sub-dimension is a significant predictor for the social citizenship consciousness competency sub-dimension ( $p$ $<.050$ ). The relation between the economic insufficiency of job sub-dimension and the social citizenship consciousness competency sub-dimension is negative and weak $(r=-.367)$. However, when the other variables are checked, this relation increases and becomes negative and medium-level $(r=-.424)$.

Table 8 . The results of the multiple regression analysis on the sub-dimensions of occupational motivation and cultural consciousness and expression competency

\begin{tabular}{|c|c|c|c|c|c|c|c|c|}
\hline & Variable & B & $\begin{array}{l}\text { Standard } \\
\text { Deviation }\end{array}$ & $\beta$ & t & $\mathrm{p}$ & Double $r$ & Limited $r$ \\
\hline \multirow{6}{*}{$\begin{array}{l}\text { Cultural Consciousness } \\
\text { and Expression } \\
\text { Competency }\end{array}$} & Constant & 5.345 & 2.094 & & 2.594 & .014 & & \\
\hline & Job Satisfaction & .147 & .073 & .429 & 2.008 & .053 & -.018 & .326 \\
\hline & Sense of Duty & -.056 & .137 & -.079 & -.406 & .687 & -.215 & -.070 \\
\hline & $\begin{array}{l}\text { Economic } \\
\text { Insufficiency of Job }\end{array}$ & -.327 & .120 & -.576 & -2.726 & .010 & -.367 & -.424 \\
\hline & $\begin{array}{l}\text { Occupational } \\
\text { Limitations }\end{array}$ & .069 & .105 & .113 & .660 & .514 & .247 & .112 \\
\hline & $\begin{array}{l}\text { Economic } \\
\text { Benefits of Job }\end{array}$ & -.145 & .093 & -.260 & -1.558 & .129 & -.199 & -.258 \\
\hline
\end{tabular}

According to the results of the regression analysis, the regression equation for the prediction of social citizenship consciousness competency is as follows: Social citizenship consciousness competency $=5.345-.327$ Economic insufficiency of job.

\section{Results, Discussions, and Suggestions}

This study investigated the correlation between occupational motivational levels and lifelong learning competencies of teachers who received postgraduate education. Any study that investigates this correlation did not found in the literature, but there were other studies that dealt with these two variables separately. According to our findings, the teachers who received postgraduate education have sufficient or very sufficient lifelong learning competencies. This result is in accordance with the results of some other studies in the field. A study by Kılıç and Ayvaz-Tuncel (2014) which investigates the individual innovativeness levels and lifelong learning dispositions of the branch teachers showed that the teachers had high-level lifelong learning competencies. Şahin and Arcakök (2014) also found that the teachers had a high-level of overall lifelong learning competency. Moreover, they also determined that the teachers had high-level competencies in the sub-dimensions of lifelong 
learning, (i.e., learning to learn and acquiring information, self-management, digital competencies, taking initiative and entrepreneurship and decision making). Kazu and Erten (2016) found that the teachers' overall lifelong learning competencies and their competencies in the self-management, learning to learn, initiative and entrepreneurship, acquiring information, digital competencies and decision making sub-dimensions of lifelong learning were high. Demirel, Sadi, and Dağyar (2016) found in their study examining the lifelong learning competencies of science teachers (i.e., natural sciences, physics, chemistry, and biology), that the teachers from all of the branches had high-level competencies in lifelong learning and all its sub-dimensions. According to another study by Özçiftçi and Çakır (2015) found that teachers studying in a distance-learning Master's program for primary school teaching had a high-level of lifelong learning competency. A study by Ayra, Kösterelioğlu, and Çelen (2016) about the lifelong learning dispositions of the primary school and branch teachers in terms of different variables found that the teachers had high-level of lifelong learning dispositions. It also revealed that the teachers had high-levels of motivation and persistence as well as the management of learning and curiosity. According to a study conducted by Paloğlu, Yılmaz, and Keser (2017) the teachers had high levels of lifelong learning disposition. Moreover, the teachers who received postgraduate education had higher lifelong learning disposition than those who did not. Özçiftçi (2014) conducted another study on 337 primary school teachers and found that the teachers had high levels of lifelong learning disposition. Similarly, Çam and Üstün (2016) conducted a study on 123 branch teachers and found that the teachers had high levels of lifelong learning disposition.

This study revealed that the teachers who received postgraduate education had high levels of occupational motivation. Some other researches working in the field support the findings of our study. According to a study conducted by Shaari, Yaakub, and Hashim (2002) $85 \%$ of 245 secondary school teachers in Malaysia belong to the high motivation category. Özdogru and Aydin (2012) conducted a study on 248 primary school teachers and 177 branch teachers (a total of 425 teachers) on this issue. They found that the overall motivation levels of the teachers were high. Moreover, the teachers' motivation levels in the sub-dimensions of the issue, which are economic motivation, psychosocial motivation, and organizational-managerial motivation, were found to be considerable. In his study conducted with 184 high school teachers, Boyle (2014) found that the motivation levels of the teachers were above average scores in some of the sub-dimensions of the motivation scale, which are recognition, economic benefit, occupational improvement, interpersonal relationships, job value, feeling of success, and work conditions. Al Tayyar (2014) conducted a study on secondary school teachers and he found that teachers were generally highlly motivated. Barl, Bilgili, Çelik, and Bayrakçeken (2005) also conducted a study on 351 teachers and determined that the teachers had high levels of occupational motivation. Similarly, Yalçın and Korkmaz (2013) conducted another study on 45 pre-school teachers to find out their levels of motivation and established that the majority of the teachers were highly motivated. Afshar and Doosti (2015) found that in general Iranian secondary school teachers seem to be satisfied with their profession and intrinsically motivated to serve the society and make a contribution to the future status of their country. Motivating factors are transferring knowledge to others, serving the society and having an internal desire to teach. Contrary to 


\section{$\Lambda$ Macrothink}

these studies, it has been determined that the occupational motivation of English teachers tends to fall in the study conducted by Scott, Cox, and Dinham (1999). Also Anthony and Ord (2008) found that English teachers possessed lower of job satisfaction when compared to Spanish teachers.

\section{References}

Afshar, H. S., \& Doosti, M. (2015). An investigation into factors contributing to Iranian secondary school English teachers' job satisfaction and dissatisfaction. Research Papers in Education, 31(3), 274-298. https://doi.org/10.1080/02671522.2015.1037335

Al Tayyar, K. (2014). Job satisfaction and motivation amongst secondary school teachers in Saudi Arabia (Published online doctoral dissertation, University of York, York).

Anthony, G., \& Ord, K. (2008). Change-of-career secondary teachers: Motivations, expectations and intentions. Asia-Pacific Journal of Teacher Education, 36(4), 359-376. https://doi.org/10.1080/13598660802395865

Aspin, D. N., \& Chapman, J. D. (2000). Lifelong learning: Concepts and conceptions. International Journal of Lifelong Education, 19(1), 2-19. https://doi.org/10.1080/026013700 293421

Ayra, M., Kösterelioğlu, İ., \& Çelen, Ü. (2016). Öğretmenlerin yaşam boyu öğrenme eğilimlerinin çeşitli değişkenler açısından incelenmesi. Hitit Üniversitesi Sosyal Bilimler Enstitüsü Dergisi, 9(1), 487-516. https://doi.org/10.17218/husbed.88537

Barlı, Ö., Bilgili, B., Çelik, S., \& Bayrakçeken, S. (2005). İlköğretim okul öğretmenlerinin motivasyonları: Farklılıkların ve sorunların araştırılması. Atatürk Üniversitesi Sosyal Bilimler Enstitüsü Dergisi, 5(1), 391-417.

Biesta, G. (2006). What's the point of lifelong learning if lifelong learning has no point? On the democratic deficit of policies for lifelong learning. European Educational Research Journal, 5(3), 169-180. https://doi.org/10.2304/eerj.2006.5.3.169

Boyle, T. P. (2014). High school teachers' and administrators' perceptions of teacher motivation factors (Unpublished doctoral dissertation, Kennesaw State University, Kennesaw).

Budak, Y. (2009). Yaşam boyu öğrenme ve ilköğretim programlarının hedeflemesi gereken insan tipi. Gazi Eğitim Fakültesi Dergisi, 29(3), 693-708.

Bümen, N. T., Ateş, A., Çakar, E., Ural, G., \& Acar, V. (2012). Türkiye bağlamında öğretmenlerin mesleki gelişimi: Sorunlar ve öneriler. Milli Eğitim Dergisi, 194, 31-49.

Büyüköztürk, Ş., Kılıç, Ç, E., Akgün, Ö. E., Karadeniz, Ş., \& Demirel, F. (2012). Bilimsel araştırma yöntemleri (11th ed.). Ankara: PegemA Yayıncılık.

Çam, E., \& Üstün, A. (2016). Öğretmenlerin mesleki tutumları ile yaşam boyu öğrenme eğilimleri arasındaki ilişki. Hitit Üniversitesi Sosyal Bilimler Enstitüsü Dergisi, 9(1), 461-477. https://doi.org/10.17218/husbed.58800 


\section{$\Lambda$ Macrothink}

Candy, P. C. (2003). Lifelong learning and information literacy. Report for U.S. National Commission on Libraries and Information Science and National Forum on Information Literacy. Retrieved February 12, 2017, from https://www.researchgate.net/publication/26829 9706_Lifelong_Learning_and_Information_Literacy/download

Coolahan, J. (2002). Teacher education and the teaching career in an era of lifelong learning. OECD Education Working Papers, 2, OECD Publishing. Retrieved July 24, 2018, from http://www.oecdilibrary.org/docserver/download/226408628504.pdf?expires=1498823107\&i $\mathrm{d}=\mathrm{id} \&$ accname $=$ guest\&checksum $=$ F52380FD98CAEC0B0753E512FAFC3DC7

Demirel, M., Sadi, Ö., \& Dağyar, M. (2016). Fen bilimleri öğretmenlerinin yaşam boyu öğrenme yeterliklerininincelenmesi (Karaman ili örneği). Pegem Ĕğitim ve Öğretim Dergisi, 6(1), 19-40. https://doi.org/10.14527/pegegog.2016.002

DPT 8. Kalkınma Planı. (2001). Hayat boyu eğitim veya örgün olmayan eğitim özel ihtisas komisyonu raporu. Retrieved February 10, 2017, from http://www.eduser.com.tr/upload/ dosya/34._dpt8.kalkinmaplanihayatbo.pdf

Erdamar, G. (2015). Yaşam boyu öğrenme. In Ö. Demirel (Ed.), Eğitimde yeni yönelimler (pp. 219-236). Ankara: Pegem Akademi.

Evin-Gencel, İ. (2013). Öğretmen adaylarının yaşam boyu öğrenme yeterliliklerine yönelik algiları. Ĕgitim ve Bilim, 38(170), 237-252.

Kazu, İ. Y., \& Erten, P. (2016). Öğretmenlerin yaşam boyu öğrenme yeterlikleri. İlköğretim Online, 15(3), 838-854. https://doi.org/10.17051/io.2016.07530

Kılıç, H., \& Ayvaz-Tuncel, Z. (2014). İlköğretim branş öğretmenlerinin bireysel yenilikçilik düzeyleri ve yaşam boyu öğrenme eğilimleri. Uluslararası Ĕ̆itim Programları ve Öğretim Çalışmaları Dergisi, 4(7), 25-37.

Latham, G. G., \& Pinder, C. C. (2005). Work motivation theory and research at the dawn of the twenty-first century. Annual Review of Psychology, 56(1), 485-516. https://doi.org/ 10.1146/annurev.psych.55.090902.142105

Özçiftçi, M. (2014). Sınıf öğretmenlerinin yaşam boyu öğrenme eğilimleri ile eğitim teknolojisi standartlarına yönelik özyeterliklerinin ilişkisi (Yayınlanmamış, yüksek lisans tezi). Amasya Üniversitesi Sosyal Bilimler Enstitüsü.

Özçiftçi, M., \& Çakır, R. (2015). Öğretmenlerin yaşam boyu öğrenme eğilimleri ve eğitim teknolojisi standartları özyeterliklerinin incelenmesi. Eğitim Teknolojisi Kuram ve Uygulama, 5(1), 1-19. https://doi.org/10.17943/etku.57410

Özdoğru, M., \& Aydın, B (2012). İlköğretim okulu öğretmenlerinin karara katılma durumları ve istekleri ile motivasyon düzeyleri arasındaki ilişki. Abant İzzet Baysal Üniversitesi Ĕgitim Fakültesi Dergisi, 12(2), 357-367.

Paloğlu, V. C., Yılmaz, R., \& Keser, H. (2017). Öğretmenlerin Yaşam Boyu Öğrenme Eğilimlerinin Incelenmesi (Özet) (p. 11). Uluslararası Bilgisayar ve Öğretim Teknolojileri 


\section{Macrothink

Sempozyumu, İnönü Üniversitesi, Malatya. Retrieved February 15, 2018, from http://icits2017.inonu.edu.tr/dosya/1494411861005342100.pdf

Şahin, Ç., \& Arcagök, S. (2014). Öğretmenlerin yaşam boyu öğrenme yeterlikleri düzeyinin çeşitli değişkenler açısından incelenmesi. Adlyaman Üniversitesi Sosyal Bilimler Enstitüsü Dergisi, 7(16), 394-417.

Şahin, M., Akbaşlı, S., \& Yanpar-Yelken, T. (2010). Key competences for lifelong learning: The case of prospective teachers. Educational Research and Review, 5(10), 545-55.

Scott, C., Cox, S., \& Dinham, S. (1999). The occupational motivation, satisfaction and health of English school teachers. Educational Psychology, 19(3), 287-308. https://doi.org/10.1080/ 0144341990190304

Shaari, A. S., Yaakub, N. F., \& Hashim, R. A. (2002). Job motivation and performance of secondary school teachers. Malaysian Management Journal, 6(1-2), 17-24.

Sharples, M. (2000). The design of personal mobile technologies for lifelong learning. Competer \& Education, 34, 177-193. https://doi.org/10.1016/S0360-1315(99)00044-5

Soran, H., Akkoyunlu, B., \& Kavak, Y. (2006). Yaşam boyu öğrenme becerileri ve eğiticilerin eğitimi programı: Hacettepe Üniversitesi örneği. Hacettepe Üniversitesi Eğitim Fakültesi Dergisi, 30, 201-210.

Tunca, N., Alkın-Şahin, S., \& Aydın, Ö. (2015). Öğretmen adaylarının yaşam boyu öğrenme eğilimleri. Mersin Üniversitesi Eğitim Fakültesi Dergisi, 11(2), 432-446. https://doi.org/ 10.17860/efd.92694

UNESCO World Report. (2005). Towards knowledge societies. Paris: UNESCO Publishing. Retrieved June 24, 2017, from http://unesdoc.unesco.org/images/0014/001418/141843e.pdf

Ural, O., \& Efe, K. (2007). Okul öncesi eğitim alanında çalışan öğretmen ve öğretmen adaylarının mesleki motivasyon düzeyleri, 1. Ulusal İlköğretim Kongresi, Ankara.

Ward, D. (2006). Revisioning information literacy for lifelong meaning. The Journal of Academic Librarianship, 32(4), 396-402. https://doi.org/10.1016/j.acalib.2006.03.006

Woonsun, K. (2014). Korean secondary school teachers' perception and need toward lifelong learning. Social and Behavioral Sciences, 116, 3506-3510. https://doi.org/10.1016/j.sbspro. 2014.01.793

Yalçın, E., \& Korkmaz, M, E. (2013). Okul öncesi öğretmenlerinin motivasyon durumları. Uluslararası Sosyal Araştırmalar Dergisi, 6(26), 602-609.

Yıldırım, R. (2017). Üniversitedeki yaşam boyu öğrenme hizmetlerinin yönetsel etkililiğinin değerlendirilmesi (Yayınlanmış doktora tezi). Çanakkale Onsekiz Mart Üniversitesi Eğitim Bilimleri Enstitüsü.

Zeynel, E. (2014). Akademisyenlere yönelik mesleki motivasyon, iş tatmini ve örgütsel bağlllık arasındaki ilişkiler üzerine bir araştırma (Yayınlanmamış doktora tezi). Süleyman 


\section{Macrothink

Demirel Üniversitesi Sosyal Bilimler Enstitüsü.

\section{Copyright Disclaimer}

Copyright for this article is retained by the author(s), with first publication rights granted to the journal.

This is an open-access article distributed under the terms and conditions of the Creative Commons Attribution license (http://creativecommons.org/licenses/by/3.0/). 